\title{
Maro sublestus Falconer, 1915 (Araneae, Linyphiidae) - a species new to the fauna of Poland
}

\author{
Paweł SZYMKOWIAK
}

\begin{abstract}
Department of Animal Taxonomy, Institute of Environmental Biology, A. Mickiewicz University, Szamarzewskiego 91 A, 60-569 Poznań, Poland; e-mail: szymkowi@amu.edu.pl
\end{abstract}

Abstract: A rare spider species, Maro sublestus Falconer, 1915 (Linyphiidae) is reported from Poland for the first time. It was found in the Karkonosze National Park, in a wet habitat. Some taxonomic comments are included in the paper.

Key words: Maro sublestus, new record, taxonomy, Poland

\section{INTRODUCTION}

The taxonomic position of the genus Maro has not been established for a long time. Saaristo (1971) in a review paper on the genus Maro concluded that this genus is closely related to the genera Agyneta, Microneta and Centromerus in conformity with the opinions expressed by Parker \& Duffey (1963). Moreover, the genera Maro and Oreonetides are regarded as relicts of mixed Arcto-Tertiary forests (Eskov 1991).

At present 12 species of the genus Maro are known. Their occurrence is limited to the northern hemisphere. The majority of species (10) occur in Europe and Asia, while Maro amplus Dondale et Buckle, 2001 and Maro nearcticus Dondale et Buckle, 2001 occur in the New World, in the USA and Canada. The species known from Europe include: Maro lehtineni Saaristo, 1971, Maro lepidus Casemir, 1961, Maro minutus O.P.- Cambridge, 1906 and Maro sublestus Falconer, 1915. The European species are characterised by small size (1-1.5 mm), although $M$. lepidus can reach up to $1.8 \mathrm{~mm}$ (Heimer \& Nentwig 1991). They are usually of pale colour and do not show pronounced sexual dimorphism (Saaristo 1971).

The Maro species most commonly met in Central Europe is M. minutus, which, because of its small size often was misidentified with other species of the same genus (Saaristo 1971). Hitherto, only $M$. minutus has been known from Poland, reported from mountainous areas in the south-western part of the country (Woźny et al. 1988). Recently, it was also reported from Roztocze, Masurian Lakeland (Staręga 1988, 1996) and in the Polesie and Biebrza National Parks (Stańska et. al. 2002, Kupryjanowicz 2003).

\section{DISTRIBUTION AND ECOLOGY}

M. sublestus is a rare European species reported from single localities mainly in Northern and Central Europe, although in Finland and Great Britain it has been found in rather great numbers (Saaristo 1971, Harvey et al. 2002). It is known also from Belgium, Czech Rep., Estonia, Ireland, Germany, Norway, Switzerland and Russia (Ural) (several authors).

According to Eskov (1991), many species of the genus Maro belong to the boreomountainous spiders. Most probably $M$. sublestus is a species of a similar type of occurrence, as indicated by the high number of its localities in the North of Europe and preference of cold and wet habitats. In Great Britain it has been recorded from wet litter of 
birch and willow also on wet heath and in fens on peat (Harvey et al. 2002). It has often been found among mosses: Hylocomium, Pleurozium and Sphagnum in marsh areas and wet meadows, also in small Sphagnum patches in spruce forests (Saaristo 1971). Other authors (Vilbaste 1964, Miller 1966, Moritz 1973, Helsdingen 1996, Ratschker 1998) found this species in wet litter with moss in highly shaded forests and in marshes. Many of its localities in Central Europe are in mountains, also in subalpine zone (Moritz 1973, Ratschker 1998, Kůrka \& Vaněk 2001, Buchar \& Růžžčka 2002, Blick 1996, 2004). Adult individuals are met in summer and autumn (Heimer \& Nentwig 1991).

\section{TAXONOMIC REMARKS}

M. minutus and M. sublestus are very similar spiders of a small body size, pale colour and are found in similar habitats. Genital structures of the female are small (epigyne length approx. $130 \mu \mathrm{m}$ ), with complex copulatory ducts. Characters helpful in identification of the female are: ratio length/width of epigynal plate, distance between spermathecae, shape of epigynal plate in lateral view, shape of black/dark pattern of the ocular area and size of AME (anterior median eyes). Drawings of the female genital structure of $M$. sublestus are given in Figs 1-4.

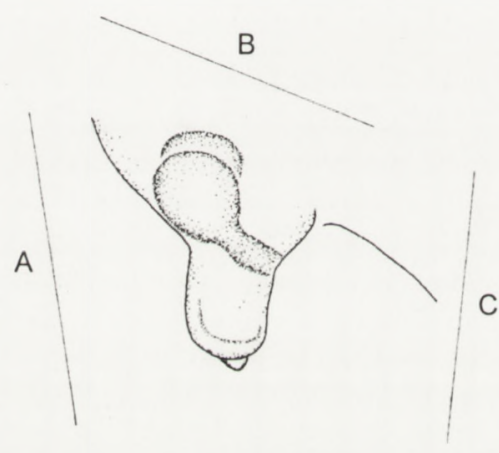

1

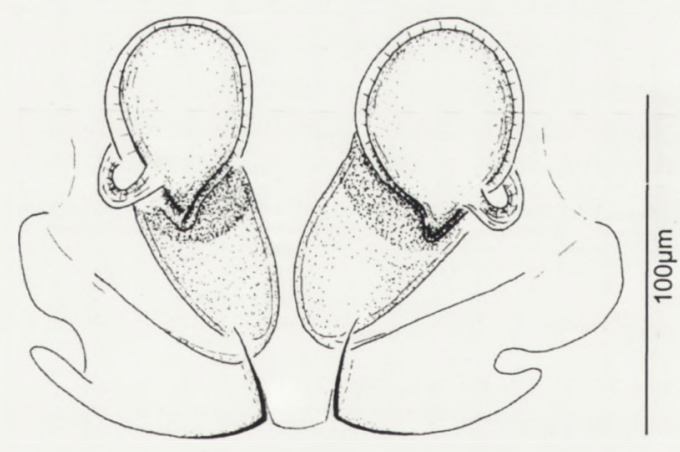

3

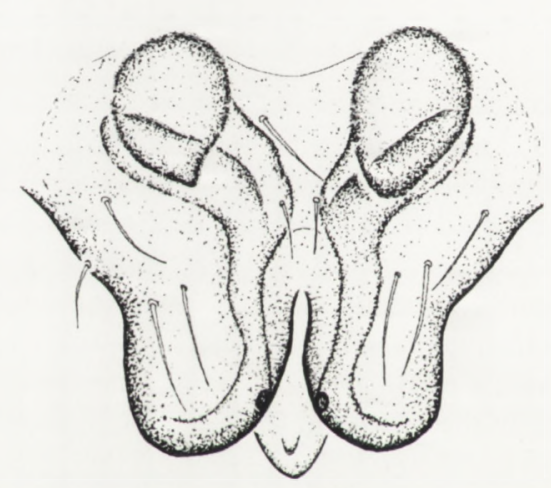

2

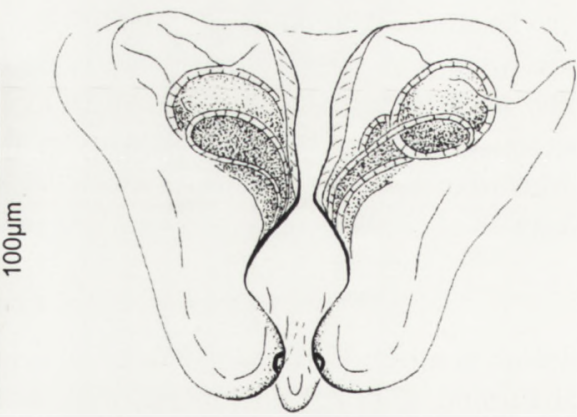

4

Fig. 1-4. Maro sublestus Falconer, 1915, female; 1 - epigyne, view from the left side with the position of drawing planes, 2 - ventral view of epigyne (A), 3 - ventral view of vulval structure (B), 4 - dorsal view of vulval structure (C). 


\section{MARO SUBLESTUS IN POLAND}

Female of M. sublestus was found during the study on the effect of artificial snowing of the skiing route "Śnieżynka" on the natural environment of the Karkonosze National Park in 20002002. The sample containing the specimen was collected on August 7, 2001, on "Śnieżynka" route (Szrenica Massif, near Szrenica Rock) (5047.938'N, $15^{\circ} 30.342^{\prime} E$; UTM WS32) at an altitude of $1169 \mathrm{~m}$ a.s.l. The locality was at the ecotone of spruce forest (Piceetum hercynicum filicetosum) and non-forest secondary communities with dominant Vaccinietum myrtylli, less abundant fern macroforbs (Athyrietum alpestris), communities with Deschampsia flexuosa and D. caespitosa and grasses from the association Calamagrostion (Dunajski 2000). The female of M. sublestus was collected from wet moss (Sphagnum), growing on a very wet area. It was accompanied by representatives of the other spider species: Ceratinella brevipes (Westring, 1851) and Erigone atra Blackwall, 1833 (Linyphiidae), Cheiracanthium erraticum (Walckenaer, 1802) (Clubionidae), Pardosa riparia (C. L. Koch, 1833) (Lycosidae), Robertus scoticus Jackson, 1914 (Theridiidae).

\section{REFERENCES}

BLICK T. 1996. Effizienzkontrolle von Landschaftspflegemaßnahmen in ausgewählten Feuchtgebieten des Fichtelgebirges: Spinnen (Arachnida: Araneae) im Raum Selb/Spielberg 1996. Unpublished report.

BLICK T. 2004. Spinnen aus dem Naturschutzgebiet und FFH-Gebiet 5937-301 Zeitelmoos im Fichtelgebirge (Lkr. Wunsiedel, Oberfranken, Bayern). Unpublished report.

BuCHAR J. \& RŮžıČKKA V. 2002. Catalogue of spiders of the Czech Republic. Praha: Press Publishers, 347 pp.

DUNAJSKI A. 2000. Identyfikacja zbiorowisk roślinnych oraz lokalizacja powierzchni do badá monitoringowych dośnieżanych tras narciarskich w rejonie Szklarskiej Poręby. Etap I monitoringu wpływu sztucznego dośnieżania na florę i roślinność tras narciarskich „Fis”, „Lolobrygida” i ,Śnieżynka” na terenie Karkonoskiego Parku Narodowego. Pracownia Ochrony Przyrody i Ekologii Krajobrazu przy Dolnóląskiej Fundacji Ekorozwoju. Wrocław: 1-16.

ESKOV K. Y. 1991. On the taxonomy and zoogeography of the spider genera Maro and Oreonetides (Aranei, Linyphiidae). Zool. Zh. 70 (4): 45-54 [in Russian].

Harvey P., Nellist D. R. \& Telfer M. G. 2002. Provisional atlas of British spiders (Arachnida, Araneae), Volume 1. Centre for Ecology \& Hydrology, Huntingdon, $214 \mathrm{pp}$.

Heimer S. \& Nentwig W. 1991. Spinnen Mitteleuropas. Paul Parey, Berlin \& Hamburg, 543 pp.

HELSDINGEN P. J. 1996. The spider fauna of some Irish floodplains. Irish Naturalists' Journal 25 (8): $285-293$.

KUPRYJANOWICZ J. 2003. Spiders (Araneae) of open habitats in the Biebrza National Park, Poland. Fragm. Faun. 46: 209-237.

KÛRKA A. \& VANĚK J. 2001. Spiders (Araneae) of shaded and non-shaded sites in the tundra of the Western Giant Mountains (Czech Republic). Opera Corcontica 38: 217-231.

Miller F. 1966. Einige neue oder unvollkommen bekannte Zwergspinnen (Micryphantidae) aus der Tschechoslowakei (Araneidea). Acta Entomol. Bohemoslov. 63: 149-164.

Moritz M. 1973. Neue und seltene Spinnen (Araneae) und Weberknechte (Opiliones) aus der DDR. Dt. Ent. Z. N.F. $20(1 / 3): 173-210$.

PARKER J. R. \& DUfFEY E. 1963. Notes on the genus Maro O.P.-C. (Araneae). Ann. Mag. nat. Hist. (13) 6: $257-263$.

RATSCHKER U. M. 1998. Erstnachweis von Maro sublestus Falconer, 1915 in Sachsen (Araneae, Linyphiidae). Arachnol. Mitt. 16: 40-42.

SAARISTO M. I. 1971. Revision of the genus Maro O.P.-Cambridge (Araneae, Linyphiidae). Ann. Zool. Fennici 8: $463-482$.

StAŃSKa M., Hajdamowicz I. \& ŻabKa M. 2002. Epigeic spiders of alder swamp forests in Eastern Poland. In: TOFT S. \& SCHARFF N. (eds), European Arachnology 2000. Proceedings of the $19^{\text {th }}$ European Colloquium of Arachnology, pp. 191-197. Aarhus University Press, Århus.

StARĘGA W. 1988. VI. Pająki (Aranei) Gór Świętokrzyskich. Fragm. Faun. 31: 185-359.

STARĘGA W. 1996. Spinnen (Araneae) aus der Borkenheide und anderen Lokalitäten der Masurischen Seenplatte. Fragm. Faun. 39: 287-311.

VILBASTE A. 1964. Eesti luhaniitude ämblikefauna struktuurist ja sesoonsetest muutustest. Eesti NSV TA Toimetised, Biol. Seeria, 13: 284-301.

Woźny M., Czajka M., Pilawski S. \& Bednarz S. 1988. Pająki (Aranei) polskich Sudetów. Acta Univ. Wratisl., Prace Zool. 19: 53-130. 


\section{STRESZCZENIE}

\section{[Maro sublestus Falconer, 1915 (Linyphiidae) - nowy dla fauny Polski gatunek pająka]}

Maro sublestus został wykazany z mchach Sphagnum rosnących na podmokłym podłożu na wysokości 1169 m n.p.m. Stanowisko znajdowało się na skraju boru świerkowego regla górnego zespołu paprociowego (Piceetum hercynicum filicetosum) oraz nieleśnych zbiorowisk zastępczych z dominującym borówczyskiem czernicowym (Vaccinietum myrtylli) w Karkonoskim Parku Narodowym. Ponadto w artykule zawarto drobne uwagi taksonomiczne.

Accepted: 28 October 2004 